\title{
NATIVE UNREST IN SOUTH AFRICA
}

\author{
By D. D. T. JABAVU, B.A.
}

INTRODUCTORY. The aboriginal black people of South Africa have not remained unaffected by the general world movement of awakening race-consciousness that is stirring all coloured peoples in Japan, China, Egypt, the United States and the British West Indies. Even politicians and press agencies can no longer afford to ignore the manifestations in native life noticeable in the various political and other organizations, in riots, and in press and platform utterances. These people slowly emerging out of barbarism, or, to use a more correct expression, out of their African civilization, have for generations remained quiet, docile, even supine in their trust in the essential goodness of Englishmen. Now a remarkable change has come over things : white men both locally and in Britain have become hardened, while on the other hand the black man himself, under the guidance of an ambitious younger generation, has developed intelligence and some feeling of independence that has made him less easy of management. The general result is that since the accomplishment of Union in 1910 there has been a steady feeling of discontentment which has been fanned into active unrest during the last four years; and unless the attitude towards the coloured races and the methods of governing them is changed there is danger that what is known as the Native Question may culminate sooner or later in some ugly collision between white and black.

The questions therefore before us are: What is the nature of this unrest? What is its origin? What should be done by white South Africa to allay it, arrest it, and to rebuild the country on a foundation that will secure the goodwill of all for all time? These questions are not easy 
to answer satisfactorily. In the limited space of a short article the writer will aim at giving impressions of outstanding factors in the great problem from the viewpoint of a Native of the soil.

Manifestations of Unrest. Amongst the many forms in which native unrest exhibits itself, the most conspicuous is that of riots and threatened riots for a living wage, as seen at Port Elizabeth, Durban, East London, Cape Town, King Williamstown and elsewhere in all the provinces.

These are an index of the degree of exasperation to which the aborigines have been brought by the unjust wages obtaining at a time of severe stress in the cost of living. The lack of consideration on the part of employers in this matter has rendered the Natives, in their disturbed state, easy victims to the belief in Marcus Garvey, whose Black Republic propaganda promises such great things. It promises among other things : the expulsion of the white man and his yoke of misrule from their midst; Negro autonomy ('I Afrika mayi buye'= Let Africa be restored to us) with Garvey himself as Lord High Potentate ; a black star fleet with powerful black armies bringing salvation, and bags of grain to relieve Africans from the economic pinch. This because of its attractiveness has made a deep impression on our illiterate people, so that even from backwood hamlets rings the magic motto 'Ama Melika ayeza' (The Americans are coming).

In 1920 the immediate causes of unrest were starvation, low wages and the high prices of life's necessaries. In almost all the big towns of the Union the commotion was visible, attaining its climax in the Port Elizabeth riots where there was considerable loss of life; and where a government commission established the fact that "while the cost of the foodstuffs and necessaries ordinarily consumed and used by natives had increased by 105 per cent the percentage of increase in wage was 60 , so that the native with 2s. 6d. a day in 1914 was really in a better position by 40 per cent than he was in 1920 with 4 s. a day.' The 
causes of trouble therefore were real, but have since been partly mitigated. With seasonable rains at Christmas (1920) followed by a satisfactory crop the situation in regard to wage earners in towns has been somewhat eased. Grievances of another type have now come to the surface, the two chief of which are the land question and the salaries of native school teachers.

The land question is many-sided. The so-called native reserves are becoming over-populated, and more land is required from somewhere. The story is the same for the Transvaal, the Transkeian territories and Eastern Cape Colony. Basutoland, for instance, has less than 10,000 square miles of habitable land for her already crowded 420,000 agrarian people who double their number every twenty-five years. Municipalities in many towns deny security of tenure to Natives who supply their town labour, reserve the right and frequently threaten to move their native inhabitants from their dwellings and sites at any time and to anywhere, and then blame these people for not beautifying their homes. How the latter can be expected to rise in the scale of civilization under such conditions it is difficult to conceive.

Again the complete embargo placed on the purchase of land by Natives in the Orange Free State (where no Native may buy land) constitutes one of the crudest anomalies in South Africa and is being more and more felt as a grievance.

Another important cause of unrest comes from the shockingly low salaries paid by Government to native teachers. The enormity of neglect in this particular can hardly be exaggerated, for the tremendous power for good this class of Native is to the state in inculcating ideas of loyalty and admiration for British justice in the hearts of the young is well known. The native teachers have not been agitators for political privileges, but to-day even they, after enduring miserable salaries long before the Great War, salaries which never enabled them to lead decent lives, salaries which to-day are worth about half the pre-war 
scale, after seeing the salaries of Europeans, Indians, and coloured teachers advanced by substantial margins, have had the chagrin of being treated as the Cinderella of the family.

Not much different is the case of the black mine-labourer whose wages have remained at about the pre-war level whilst his white supervisors, through their trade union, have had theirs sent up to exorbitant figures. The system of artificial colour-bar laws with exploitation of the black man's sweat and blood is already producing a deep but quiet feeling of resentment in the black man's heart. Not infrequently does one hear private discussion on these lines : 'If the white man is really superior to us, as he vehemently claims, then why does he bolster up his superiority over us by colour-bar legislation? Why does he fear black and Indian merchants? Why does he preclude the African from showing what he can do in his alleged inferiority?' So much for the actual items of unrest. We shall now examine the ground in which this unrest is nurtured.

Factors making for Unrest. Among factors making for a charged atmosphere is the fact that a number of better educated native young men, some apparently without regular employment, who carry weight with the rank and file of native labourers, influence the latter in one way and another on political and other burning questions affecting their life, and continually raise funds for one project or another. They are often mistaken by the European public for vindictive and anti-white malcontents. In truth they are the product of the many social and economic pin-pricks of injustice so universally to be found in the Orange Free State and Transvaal. The influence of the press in South Africa, where there is little independent thought, is greater both for good or for bad than, say, in Europe. And it is unfortunate that in many towns press agencies do not avail themselves more of the opportunities of allaying the spirit of ill-will than they do. For example, the proceedings of a very important General Missionary 
Conference at Durban, that admittedly handled the native question with thorough investigation and arrestingly business-like methods, received barely a few inches in the press summary as compared with columns on horse-racing, lawsuits and other matter of small national significance. Crime is often the only form of public advertisement for the Native. Undue prominence is given to occasional 'black peril' cases and yellow scares, instead of to much valuable constructive work that is being quietly done by both white and black. The native press, lacking in educated native contributors, has frequently erred in being either too ineffectively docile or, on the other hand, too inflammatory. By these varied circumstances native public opinion has been influenced and developed for many years until the old love for, and confidence in, British impartiality has been undermined. Since the Boer War of 1900 and through various political happenings ${ }^{1}$ the Natives have gradually lost confidence in the even-handedness of British institutions, particularly in the Northern provinces. Just as it has taken twenty years for them to lose this confidence so it is going to require more than one generation to restore it.

Again, the South African racial atmosphere of reserve and suspicion will not help matters, because race relations here are artificially strained and unnatural as compared with those in, say, the West Indies, Dahomey and Great Britain. For instance, during my eleven years in England I constantly admired the Englishman's spirit of open-mindedness, justice and real goodness towards foreigners. In sport he was fairness personified, adoring the brilliant Indian cricketers and upholding negro boxers even at the expense of his own race. In social intercourse it was frequently an advantage to be a black man. The Bantu in South Africa have long known that when a white man first arrives from England he is full of love for the black people. But in a few months he is compelled by his fellow whites, at the threat of social

I See further particulars in my book, The Black Problem. Lovedale: The Book Department. London: Friends' Bookshop, I40 Bishopsgate, E.C. 4 s. 4 d. I920. 
ostracism, to change. Cases of this are innumerable in ordinary life, whilst mission circles too are in some cases not wholly without it nowadays. The necessity for maintaining this false atmosphere is seriously upheld by semi-educated whites everywhere in South Africa. To take one typical letter in a voluminous anti-native correspondence in the Bloemfontein Farmer's Weekly, in a lengthy and ambitious article on what is called 'First Principles and Heredity' long-exploded pseudo-scientific theories are propounded as new discoveries :

The difference intellectually between the Negro and European races is irrevocably fixed by the limitations set by skull formation and heredity; . . . the natural place of the Negro races in South Africa is to remain hewers of wood and drawers of water; and until our native policy is based upon the scientific and candid recognition of this fact, we shall find no practical or workable solution of the Native Question.

This is the guiding theory followed by many, however amusing it must be to Jean Finot and modern ethnologists and sociologists.

Next, the effects of the world war constitute a powerful factor in the development of native mentality. The Bantu were taken by surprise that European nations who led in education and Christianity should find no other means than the sword and accumulated destructive weapons to settle their diplomatic differences. Their vast contingent of labourers drawn from every tribe visited France, and returned to educate every section of the Bantu on the goodness of whites in Europe as against the hardness of whites in South Africa. The war has awakened an otherwise long-dormant race-consciousness in the Bantu, as witness : (a) a spirit of union and growing tendencies for organization on trade-union lines, specially among labourers and teachers against European exploitation and injustice; (b) a general desire for higher and sounder education, the present training schools being overwhelmed with pupils in the worst years of drought and high prices (1917-1920); (c) the spread of religious separatist movements (for instance 
in one native township near Johannesburg there are no less than 32 native churches for the spiritual needs of only a few thousand people; in Pretoria it is said there are 63, while the Union Government has registered 106. Some flourish with interesting names such as Bethesda Zion Apostolic, African United Gaza, Natural Church of Ethiopia, Pentecostal Holiness, Christian Catholic Church in Zion, etc.); $(d)$ the evidence of a self-assertive attitude against petty sub-officials who annoyingly impose their authority upon the 'school Native.'

The fact can no longer be concealed that in many of the smaller up-country towns where the European is harsh towards the Bantu a sense of deep contempt for, and resentment against, the white man is unfortunately becoming more and more widespread. ${ }^{\prime}$ And unless a sympathetic spirit becomes speedily diffused among the whites, confidence in British equity will in time become totally extinguished. This is expressing in mild terms the situation in the Transvaal. Here as in all the other affairs of life it is easier to destroy than to construct. The lasting impression of goodwill left in the memories of the non-European population of South Africa by Queen Victoria took generations to establish. In spite of the treatment under the Dutch régime in the Orange Free State and the Transvaal when a black-skinned man was regarded as no better than a baboon ('zomaar bobejaan') the Basuto and the Bechuana races so implicitly believed in the English and 'Mofumahali' Victoria that their leaders, Chief Moshoeshoe and King Khama spontaneously and voluntarily handed over their people and territories, though unconquered, to the tutelage of the Great Queen and the English nation. This confidence lasted until the Boer War, when it was shaken to its foundation at the annexation of the Dutch republics by a series of events : the Treaty of Vereeniging 1901 (when Englishmen for the first time gave way on their principle of 'Equal

\footnotetext{
' See a pamphlet of anti-European poerns, The Dark Musician of the Northern
} Transvaal, by Moses Mpahlele of Pietersburg. 
rights for all civilized men south of the Zambesi ' by conceding to the Dutch the denial of the franchise to the Bantu); Bambata's rebellion in 1906 (against an oppressive poll tax) ; the Union Act in 1910 (entrenching colour discrimination in legislation); the Lands Act in 1913 (with its cruel evictions in the Orange Free State) and others mentioned in my Black Problem.

It is remarkable how the attitude of the Englishman, long famed for magnanimity, has been considerably changed towards a compromise with the negrophobist Orange Free State ideas, whilst the Dutch, with a strong anti-native tradition have, to their credit, somewhat toned down and become more humane than they were in 1898 in the Transvaal, and have actually produced a number of first-rank statesmen, as the world has reason to know.

The Native, too, is by his development contributing unconsciously to this atmosphere of change. $\mathrm{He}$ is frequently referred to as a child, a child-race that must be guided and protected by his white guardian. Yes, but this child is no longer a baby; he is growing big, big enough to speak and ask some awkward questions, becoming precocious, irrepressible, and perhaps unruly at times, but nevertheless needing sympathy, without which he cannot grow on right lines, though grow he will and must. He wants all encouragement, but does he always get it ? The white man himself replies, 'In practice the Native receives very little encouragement, outside of the Transkei, to cultivate his land better ; indeed we have known of European farmers looking with great disfavour on any attempt on the part of native cultivators to increase production.' They must learn to help themselves, hence the origin of bodies like "The Native and Coloured Industrial and Commercial Workers' Union' and their well-known activities directed against the exploitation of native labour. They are working on lines of organization and agitation as the only means of securing fair wages.

Conclusrons. South Africa has always been in need 
of scientific men and psychologists prepared to devote their time and brains to a thoroughgoing study of the Native Question, because most Europeans, including those who have had much to do with ruling the Africans, have not troubled themselves to understand the mind of the black man and its peculiar ways, while most Natives, including the bettereducated class, understand only the external character of the white man but cannot know his inner soul and ideals without having lived with him on various social levels and on terms approximating to equal social intercourse.

One exemplary method of doing this, although it has hitherto had little advertisement, is that of the ethnological studies carried on by the South African Association for the Advancement of Science (notably the papers by Dr C. T. Loram, Rev. J. R. L. Kingon, etc.) and by the South Africa General Missionary Conference (with papers like those of the Rev. F. Goring, Dr N. Macvicar, etc.). In these papers it is made abundantly clear that the Bantu cannot be successfully administered as one homogeneous population. Opportunities must be given for those who have advanced in civilization to obtain suitable outlets for their capability. To repress them is impracticable.

A step in the right direction is the Native Affairs Act of 1920, which is a credit to General Smuts. The Commission appointed under that Act is already proving to be a boon to the country; on the one hand Cabinet Ministers refer to it all perplexing legislation when faced by awkward questions in Parliament, while on the other hand the native people utilize it as a tribunal before which to voice their grievances at length, thus obtaining the satisfaction of having their affairs seriously considered. For one party it is a convenient refuge, for the other a useful safety-valve for letting out steam. At best, however, it is only a good beginning, for it is inconceivable that Natives as a whole will ever be satisfied until they have full power of control over their taxation, revenue and its distribution. Whether this can best be done by."granting them a sort of imperium 
in imperio, or otherwise, remains to be seen. A wise step here would be the institution of a special Ministry of Native Affairs with a full-time minister taking charge of all the interests of Natives, as has lately been urged in the European and native press; the present arrangement satisfies nobody. Certainly the present position of taxation without representation cannot last long without bringing the entire nonEuropean population into lines of direct conflict with the South African Government. The troublesome Transvaal poll $\operatorname{tax}$ agitation is an illustration of this.

The coloured races (and here one includes Indians, Hottentots, mixed-blooded coloured peoples and Bantu) need to substitute for untrained leaders a number of intellectual spokesmen of the type of Booker $T$. Washington, J.E.K. Aggrey and R.R. Moton, among the American Negroes, who will call attention in a vigorous but constitutional manner to some of the glaring examples of injustice (such as the municipalities who use their native revenue for other than native purposes), throw light upon the conditions in the Reserves (Transkei, Zululand, Rhodesia), expose the evils of the pass laws (whereby Natives are treated as prisoners of war), the jury system, etc., and who will at the same time furnish constructive schemes for the amelioration of the conditions of their people, on lines of co-operation with the friendly section of the whites.

On the part of the rulers, certain principles deserve study : the better educated Natives cannot be neglected in legislative affairs by reason of their small percentage as compared with the masses. If they are allowed to become disaffected their influence will react injuriously to the country.

The various missionary societies, while they have in their proper and traditional manner supplied the spiritual and educational needs of the Bantu with conspicuous success cannot, however, afford to stop there in their work. For with quickened race-consciousness the Bantu, in the words of missionaries themselves, "claim to be allowed a 
larger share, or even absolute control in the organization of the Church and the direction of ecclesiastical concerns.' These demands are not unjust, and missionaries, being in loco parentis, should be patient and meet them in the way that has been adopted by the United Free Church of Scotland of late. If no consideration is accorded him in this respect then the black man's Christianity, through the prevalent divisive tendencies, will continue to sink deeper into chaos. Under this head one should mention that religious bodies at the home base should make greater use of their juvenile organizations in inculcating a spirit of friendliness towards foreign races. Members of the Y.M.C.A. and the Student Christian Movements should, out of higher spiritual patriotism, seek work as teachers in our native secondary schools as far as that is possible, with the purpose of applying the principles of Christianity in a practical fashion to counteract the growing contempt which the Natives are developing for white Christians who preach to them at length without living out their message. Such practical testimony of a true Christian life goes much further than any amount of philanthropic donations to African missions. The social uplift of the benighted races must be regarded as being as important as preaching, for it is there that the missionaries can best show the depth of their sympathy and love. Black people are easy to manage if you love them, for they are emotionally sensitive and quick to respond; otherwise they are difficult. After all this is true of most human beings.

The European races of South Africa will solve their Native Question when, and probably only when, they as a whole make a serious endeavour to deal with the Bantu people in a sympathetic spirit, which in the last analysis is founded on our Lord's gospel dictum 'Love thy neighbour as thyself.'

$$
\text { D. D. T. JABAvU }
$$

